\title{
Studi Kasus: Asuhan Keperawatan Jiwa Dengan Gangguan Persepsi Sensori : Halusinasi Pada Penderita Skizofrenia
}

\author{
Nazela Nanda Putri, Nora Lissa Octavia Nainggolan, Novia, Sani Vandea \\ Merisa Saragih, Sasmita, Asaniaman \\ nazelanandaputri261@gmail.com
}

\begin{abstract}
BAB 1
PENDAHULUAN

Gangguan jiwa merupakan masalah kesehatan yang serius karena jumlah penyakit yang terus menerus meningkat, termasuk penyakit kronis seperti skizofrenia yang mempengangaruhi proses berpikir bagi penderitanya. Akibatnya penderita skizofrenia sulit berpikir jernih, kesulitan menejemen emosi dan kesulitan bersosialisasi dengan orang lain.(Hairani, Kurniawan, Latif \& Innudin, 2021). Skizofrenia merupakan suatu penyakit yang mempengaruhi otak dan menyebabkan timbulnya pikiran, emosi, persepsi, gerakan dan perilaku yang aneh (Fatturahman, Putri \& Fradianto 2021).
\end{abstract}

\section{Latar Belakang}

Skizofrenia merupakan sekelompok reaksi psikotik yang mempengaruhi berbagai area fungsi individu, termasuk berpikir, berkomunikasi, merasakan dan menunjukkan emosi serta gangguan otak yang ditandai dengan pikiran kacau, waham, halusinasi, dan perilaku aneh (Pardede \& Ramadia, 2021). Menurut ECA (2021). Prevelensi Amerika Serikat askizofrenia telah meningkat dari 30\% jiwa. Sedangkan di Indonesia prevelensi skizofrenia meningkat menjadi $25 \%$ penduduk. Prevelensi Sumatera utara meningkat menjadi $7 \%$ penduduk (Riskesdes 2018)

Berdasarkan peningkatan Pasien skizofrenia, perubahan respon persepsi merupakan gejala pertama yang muncul pada Skizofrenia. Sekitar 70\% Pasien Skizofrenia mengalami halusinasi (Stuart, Keliat \& Pasaribu, 2016). 
Halusinasi merupakan suatu persepsi panca indera tanpa adanya stimulus eksternal. Klien dengan halusinasi sering merasakan keadaan/kondisi yang hanya dapat dirasakan olehnya namun tidak dapat dirasakan oleh orang lain. (Nurlaili, Nurdin, Putri, Arif, Basmanelly, \& Fernandes, 2019).

Dampak yang ditimbulkan dari adaya halusinasi adalah kehilangan Social diri, yang mana dalam situasi ini dapat membunuh diri ,membunuh orang lain, bahkan merusak lingkungan. Dalam memperkecil dampak yang ditimbulkan halusinasi dibutuhkan penangan yang tepat. Dengan banyaknya kejadian halusinasi, semakin jelas bahwa peran perawat nntuk membantu pasien agar dapat mengontrol halusinasi (Maulana, Hernawati \& Shalahuddin, 2021).

Dalam penanganan halusinasi sudah di tangani beberapa terapi keperawatan seperti Terapi Strategi pelaksanaan adalah penerapan standar asuhan keperawatan terjadwal yang diterapkan pada pasien yang bertujuan untuk mengurangi masalah keperawatan jiwa yang ditangani. Strategi pelaksanaan pada pasien halusinasi mencakup kegiatan mengenal halusinasi, mengajarkan pasein menghardik, minum obat dengan teratur, bercakap-cakap dengan orang lain saat halusinas muncul, sertamelakukan aktivitas terjadwal utuk mencegah halusinasi (Livana, Rihadini, Kandar, Suerni, Sujarwo, Maya \& Nugroho. 2020) dan Terapi musik klasik dalam dapat mengubah perilaku yang awalnya berperilaku maladaptive ke perilaku adaptif pada pasien halusinasi pendengaran. Teknik ini dapat membantu klien mengubah perilaku yang dari negatif menjadi pasitif (Wijayanto \& Agustina, 2017).

Berdasarkan Survey awal pada pelaksanaan asuhan keperawatan jiwa pada skizofrenia ini dilakukan di Ruang Bukit Barisan terdapat jumlah pasien 27 orang dan yang menjadi subjek berjumlah 1 orang dengan pasien gangguan persepsi sensori : Halusinasi Pendengaran atas nama Tn. R. Penyebab Tn. R dijadikan sebagai subjek dikarenakan pasien masih sering mendengar suarasuara bisikan. 
Berdasarkan Latar Belakang penulis tertarik mengambil judul "Asuhan keperawatan Halusinasi pendengaran Tn.R di Ruang Bukit Barisan"

\subsection{Rumusan Masalah}

Berdasarkan masalah yang telah dipaparkan pada latar belakang maka rumusan masalah dalam askep ini yaitu Asuhan keperawatan Halusinasi pendengaran Tn. R di Ruang Bukit Barisan.

\subsection{Tujuan Penulisan}

\subsubsection{Tujuan Umum}

Untuk memberikan asuhan keperawatan jiwa pada Tn. $\mathrm{R}$ dengan gangguan persepsi sensori : Halusinasi

\subsubsection{Tujuan Khusus}

1. Mahasiswa mampu mengetahui defenisi, tanda dan gejala, faktor, penyebab, mekanisme koping penatalaksanaan pada pasien halusinasi

2. Mahasiswa mampu melakukan pengkajian pada Tn.R dengan halusinasi

3. Mahasiswa mampu menegakkan diagnosa atau masalah keperawatan pada Tn. R

4. Mahasiswa mampu melakukan intervensi keperawatan pada Tn. $\mathrm{R}$

5. Mahasiswa mampu melakukan implementasi keperawatan pada Tn.R

6. Mahasiswa mampu melakukan evaluasi keperawatan pada Tn. R

7. Mahasiswa mampu melakukan pendokumentasian pada Tn. R

\section{BAB 2}




\subsection{Konsep Halusinasi}

\subsubsection{Defenisi}

Halusinasi merupakan distorsi persepsi palsu yang terjadi pada respon neurobiologist maladaptive, penderita sebenarnya mengalami distorsi sensori sebagai hal yang nyata dan meresponnya (Pardede, 2020). Halusinasi adalah suatu gejala gangguan jiwa. Pasien mengalami perubahan sensori persepsi merasakan sensasi palsu berupa suara, penglihatan, pengecapan, perabaan atau penghiduan. Pasien merasakan stimulus yang sebetulnya tidak ada (Dermawan, 2018). Halusinasi adalah persepsi klien terhadap lingkungan tanpa stimulus yang nyata, artinya klien mengiterprestasikan sesuatu yang tidak nyata stimus/rangsangan dari luar (Manulang, 2019).

Halusinasi merupakan gangguan jiwa dimana klien mengalami perubahan persepsi sensori, merasakan sensasi palsu berupa suara, penglihatan, rasa, sentuhan, atau penciuman (Abdurkhman \& Maulana 2022). Halusinasi merupakan persepsi yang diterima oleh panca indera tanpa adanya stimulus eksternal. Klien dengan halusinasi sering merasakan keadaan/kondisi yang hanya dapat dirasakan olehnya namun tidak dapat dirasakan oleh orang lain (Harkomah,2019). Berdasarkan beberapa defenisi diatas halusinasi merupakan gangguan persepsi panca Indera ,adanya stimulus eksternal yang merasakan sensasi palsu namun tidak dapat dirasakan oleh orang lain.

\subsubsection{Tanda dan gejala}


Menurut Azizah, Zainuri \& Akbar, (2016). Tanda dan gejala halusinasi penting diketahui oleh perawat agar dapat menempatkan masalah halusinasi antara lain :

1. Berbicara, tertawa dan tersenyum sendiri

2. Bersikap seperti mendengarkan sesuatu

3. Berhenti berbicara sesaat ditengah-tengah kaimat untuk mendengarkan sesuatu

4. Disorientasi

5. Tidak mampu atau kurang konsentrasi

6. Cepat berubah pikiran

7. Alur Social kacau

8. Respon yang tidak sesuai

9. Menarik diri

10.Respon yang tidak sesuai

11.Suka marah dengan tiba- tiba dan menyerang orang lain tanpa sebab.

12.Sering melamun

\subsubsection{Faktor- Faktor Yang Mempengaruhi Halusinasi}

a. Faktor predisposisi

Faktor kerentanan merupakan Social risiko yang mempengaruhi jenis dan jumlah sumber yang dapat dikemukakan individu untuk mengatasi Social. Diperoleh dari pelanggan dan keluarganya. Faktor pencetus mungkin termasuk

1. Faktor Perkembangan

Jika tugas perkembangan menemui hambatan dan hubungan interpersonal terputus, individu akan merasa Social dan cemas (Zelika \& Dermawan, 2015). Tugas perkembangan klien yang terganggu misalnya rendahnya Social dan kehangatan keluarga menyebabkan klien tidak mampu mandiri sejak kecil,mudah frustasi, hilang percaya diri, dan lebih rentan terhadap stress (Sutejo, 2020). Berdasarkan beberapa defenisi diatas social perkembangan jika kehangatan dalam keluarga yang rendahnya 
control menybabkan klien tidak mampu mandiri sejak dini, hilang percaya diri dan lebih rentan terhadap stress

2. Faktor Sosial Dan Budaya

Faktor berbagi dalam masyarakat dapat membuat orang merasa dikucilkan, dan dengan demikian membuat orang merasa kesepian di lingkungan mereka yang luas (Sutejo, 2020). Seseorang yang merasa tidak diterima dilingkungan sejak bayi sehingga akan merasa kesepian dan tidak percaya pada lingkungannya (Zelika \& Dermawan, 2015)

Berdasarkan beberapa defenisi diatas social social dan budaya dalam lingkungan masyarakat dan keluarga yang sering dikucilkan dan akan merasa kesepian dan tidak percaya pada lingkungan

\section{Faktor Biokimia}

Hal tersebut berdampak pada terjadinya gangguan jiwa. Jika seseorang mengalami social yang berlebihan, tubuh menghasilkan zat kimia saraf yang dapat menyebabkan halusinasi, seperti buffalophenone dan dimethyltransferase (DMP) (Sutejo, 2020)

Hal ini berpengaruh terhadap terjadinya gangguan jiwa. Adanya stress berlebihan dialami seseorang maka didalam tubuh akan berlebihan dialami seseorang maka didalam tubuh akan dihasilkan suatu zat yang bersifat halusiogenik neurokimia. Akibat stress berkepanjangan menyebabkan teraktivitasnya neurotransmitter otak misalnya terjadi ketidakseimbangan acetylchoin (Zelika \& Dermawan, 2015) 
Berdasarkan beberapa defenisi diatas Social biokimia merupakan yang dimana stress berkepanjangan menyebabkan teraktivitasnya neurotransmitter otak misalnya ketidak seimbangan acetychoin dopamine.

\section{Faktor Psikologi}

Hubungan interpersonal tidak harmonis, dan biasanya seseorang menerima berbagai peran yang kontradiktif, yang akan menimbulkan banyak Social dan kecemasan, serta berujung pada hancurnya orientasi realitas (Sutejo, 2020)

Tipe kepribadian lemah dan tidak bertanggung jawab mudah terjerumus pada penyalahgunaan zat adiktif. Hal ini berpengaruh pada ketidakmampuan klien mengambil keputusan tegas, klien lebih suka memilih kesenangan sesaat dari lari dari alam nyata menuju alam khayal (Zelika \& Dermawan, 2015). Berdasarkan beberapa defenisi diatas social psikologi terlalu banyak stress dan kecemasan serta berujung pada hancurnya orientasi realitas.

\section{Faktor Genetik}

Penelitian telah menunjukkan bahwa anak-anak sehat yang dirawat oleh orang tua Pasien skizofrenia lebih mungkin mengembangkan skizofrenia. Hasil penelitian menunjukkan bahwa Social keluarga memiliki pengaruh yang sangat penting terhadap penyakit ini (Dermawan, 2016).

\section{b. Faktor presipitasi}

Faktor presipitasi merupakan stimulus yang dipersepsikan oleh individu sebagai tantangan, ancaman, atau tuntutan yang memerlukan social ekstra untuk menghadapinya. Adanya rangsangan dari lingkunagan, seperti partisipasi klien dalam kelompok, terlalu lama tidak diajak komunikasi, objek yang ada di 
lingkungan, dan juga suasana Sosial terisolasi seringg menjasi pencetus terjadinya halusinasi. Hal tersebut dapat meningkatkan Social dan kecemasan yang merangsang tubuh mengeluarkan zat halusinogenik (Stuart, Keliat \& Pasaribu 2016)

\subsubsection{Jenis-Jenis Halusinasi}

Jenis-jenis halusinasi terbagi menjadi 4 antaranya:

1. Halusinasi pendengaran

Mendengar suara-suara atau kebisingan, paling seperti suara orang suara berbentuk kebisingan yang kurang keras sampai kata-kata yang jelas berbicara tentang klien, bahkan sampai percakapan lengkap antara dua orang atau lebih. Pikiran yang didengar klien dimana pasien disuruh untuk melakukan sesuatu yang kadangkadang membahayakan (Muhit, 2016). Halusinasi pendengaran adalah mendengar suara atau bunyi yang berkisar dari suara sederhana sampai suara berbicara mengenai klien sehingga klien berespon terhadap suara atau klien bunyi tersebut (Harkomah, 2019)

Berdasarkan beberapa defenisi diatas Halusinasi pendengaran merupakan mendengar suara atau bunyi yang serderhana seperti kebisingan, suara bercakap-cakap, sehingga klien berespon terhadap suara dan bunyi tersebut.

\section{Halusinasi penglihatan}

Stimulus visual dalam bentuk kilatan cahaya gambaran geometris, gambaran kartun, banyangan yang rumit dan kompleks. Bayangan menyenangkan atau menakutkan seperti melihat monster (Muhit, 2015). Halusinasi penglihatan adalah yang dimana kontak mata kurang, senang menyendiri, terdiam dan memandang kesuatu sudut dan sulit berkonsentrasi (Erviana \& Hargiana, 2018). Berdasarkan beberapa defenisi diatas Halusinasi merupakan gangguan 
penglihatan yang stimulus visual dalam bentuk klitan cahaya, gambar geometris, dapat dilihat dari kontak mata kurang, senang menyendiri, dan sulit berkonsentrasi.

\section{Halusinasi penghidu}

Membaui bau- bauan tertentu seperti daah, urin, atau feses, umumnya bau-bauan yang tidak menyenangkan. Halusinasi penghidu sering akibat stroke, tumor, kejang atau demensia (Muhit, 2015). Karakteristik ditandai dengan adanya bau busuk, amis dan bau yang menjijikan seperti darah,urine atau fases kadang tercium bau harum (Yusalia, 2018). Berdasarkan beberapa defenisi diatas halusinasi penghidu merupakan gangguan penciuman bau yang biasanya ditandai dengan membaui aroma seperti darah, urine dan fases terkadang membaui aroma segar.

\section{Halusinasi Pengecapan}

Merasa seperti mengecap rasa seperti darah,urin atau feses (Muhit, 2015)

\section{Halusinasi sentuhan}

Merasa disentuh, disentuh, ditiup, dibakar, atau bergerak di bawah kulit seperti ulat (Muhit, 2015)

\subsubsection{Rentang respon}

Halusinasi adalah reaksi maladaftif individu yang berbeda Rentang respons neurobiologis (Stuart, Keliat \& Pasaribu, 2016). Ini adalah perasaan maladaptasi. Jika pelanggan memiliki pandangan yang sehat Akurat, mampu mengenali dan menafsirkan rangsangan Menurut panca indera (pendengaran, Penglihatan, penciuman, rasa dan sentuhan)

pelanggan halusinasi Bahkan jika stimulusnya di antara kedua tanggapan tersebut terdapat tanggapan yang terpisah Karena satu hal mengalami sosial yang abnormal, yaitu kesalah pahaman Stimulus yang 
diterimanya adalah ilusi. Pengalaman Pasien yang luas Jika penjelasan untuk stimulasi sensorik tidak Menurut stimulus yang diterima, rentang responsnya adalah sebagai berikut:

\section{RESPON ADAPTIF $\longrightarrow$ RESPON MALADATIF}

\begin{tabular}{|l|l|l|}
\hline - Pikiran logis & $\bullet$ Distorsi pikiran & $\bullet$ Gangguan piker \\
- Persepsi akurat & $\bullet$ Ilusi & $\bullet$ Sulit merespon \\
- Emosi konsisten & $\bullet$ Reaksi emosional & emosi \\
dengan pengalaman & $\bullet$ Perilaku & $\bullet$ Perilakku \\
- Perilaku sesuai & anah/tidak biasa & disorganisasi \\
- Berhubungan soial & $\bullet$ Menarik diri & $\bullet$ Isolasi sosial \\
\hline & \multicolumn{3}{|c|}{ Tabel 2.1 } \\
\hline
\end{tabular}

\subsubsection{Tahapan Halusinasi}

Tahapan halusinasi menurut Azizah, Zainuri \& Akbar (2016) anatara lain:

a. Tahap pertama (non-psikotik)

Pada tahap ini, halusinasi dapat membuat klien merasa nyaman dan orientasi sedang. Secara umum pada tahap ini merupakan hal yang menyenangkan bagi klien : Mengalami kecemasan, kesepian, batin dan ketakutan,Cobalah untuk social pada pikiran yang dapat menghilangkan kecemasan dan Pikiran dan pengalaman indrawi masih di bawah kendali sadar.

Perilaku yang muncul:

1. Tersenyumlah atau tertawakan diri Anda sendiri

2. Gerakkan bibir Anda dengan tenang

3. Gerakan mata yang cepat

4. Sebarkan respons verbal, diam dan konsentrasi

b. Fase 2 (pasien non-psikiatri) 
Pada tahap ini, pelanggan biasanya menyalahkan diri sendiri dan merasakan kecemasan yang serius. Biasanya rasa haus yang ada social menyebabkan rasa jijik.klien: Pengalaman sensorik yang menakutkan atau terganggu oleh pengalaman, mulai merasa lepas kendali dan keluar dari orang lain

Perilaku yang muncul:

1. Meningkatnya detak jantung, pernapasan, dan tekanan darah

2. Mengurangi kepedulian terhadap lingkungan

3. Fokus pada pengurangan pengalaman sensorik

4. Hilangnya kemampuan untuk membedakan antara ilusi dan kenyataan

c. Tahap ketiga (penyakit mental)

Klien biasanya tidak dapat mengontrol diri mereka sendiri, kecemasan mereka parah, dan halusinasi sangat menarik klien : Pasien menyerah dan menerima pengalaman sensorik, isi ilusi menjadi menarik dan ketika pengalaman selesai pasien menjadi kesepian.

Perilaku yang muncul:

1. Pasien mematuhi instruksi halusinasi

2. Kesulitan berhubungan dengan orang lain

3. Sedikit atau perhatian sementara terhadap lingkungan

4. Tidak dapat mengikuti perintah sebenarnya

5. Pasien terlihat panas dan berkeringat

d. Tahap keempat (penyakit mental klien mudah dikendalikan oleh halusinasi, dan mereka biasanya panik).

Perilaku yang muncul:

1. Risiko cedera tinggi 
2. Pengadukan

3. Ketidakmampuan merespon rangsangan yang ada

\subsubsection{Komplikasi}

Halusinasi dapat menjadi suatu alasan mengapa pasien melakukan tindakan perilaku kekerasan karena suara-suara yang memberinya perintah sehingga rentan melakukan perilaku yang tidak adaptif. Perilaku kekerasan yang timbul pada pasien skizofrenia diawali dengan adanya perasaan tidak berharga, takut dan ditolak oleh lingkungan sehingga individu akan menyingkir dari hubungan interpersonal dengan orang lain (Keliat, 2016). Komplikasi yang dapat terjadi pada klien dengan masalah utama gangguan sensori persepsi: halusinasi, antara lain: resiko prilaku kekerasan, harga diri rendah dan isolasi sosial

\subsubsection{Penatalaksanaa Medis}

Halusinasi merupakan salah satu gejala yang paling sering terjadi pada gangguan Skizofrenia. Dimana Skizofrenia merupakan jenis psikosis, adapun tindakan penatalaksanaan dilakukan dengan berbagai terapi yaitu dengan:

\section{Psikofarmakologis}

Obat sangat penting dalam pengobatan skizofrenia, karena obat dapat membantu pasien skizofrenia untuk meminimalkan gejala perilaku kekerasan, halusinasi, dan harga diri rendah. Sehingga pasien skizofrenia harus patuh minum obat secara teratur dan mau mengikuti perawatan (Pardede, Keliat, Wardani, 2013) :

a. Haloperidol (HLD)

Obat yang dianggap sangat efektif dalam pengelolaan hiperaktivitas, gelisah, agresif, waham, dan halusinasi.

b. Chlorpromazine (CPZ)

Obat yang digunakan untuk gangguan psikosis yang terkait skizofrenia dan gangguan perilaku yang tidak terkontrol

c. Trihexilpenidyl (THP) 
1) Dosis

a. Haloperidol 3x5 mg (tiap 8 jam) intra muscular.

b. Clorpromazin $25-50 \mathrm{mg}$ diberikan intra muscular setiap 6-8 jam sampai keadaan akut teratasi.

2) Dalam keadaan agitasi dan hiperaktif diberikan tablet:

b. Haloperidol $2 \times 1,5-2,5 \mathrm{mg}$ per hari.

c. Klorpromazin $2 \times 100 \mathrm{mg}$ per hari

d. Triheksifenidil $2 \times 2 \mathrm{mg}$ per hari

3) Dalam keadaan fase kronis diberikan tablet:
a. Haloperidol 2x0,5 - $1 \mathrm{mg}$ perhari
b. Klorpromazin 1x50 mg sehari (malam)
c. Triheksifenidil 1-2x2 mg sehari
d. Psikosomatik

2. Terapi kejang listrik (Electro Compulsive Therapy), yaitu suatu terapi fisik atau suatu pengobatan untuk menimbulkan kejang grand mal secara artifisial dengan melewatkan aliran listrik melalui elektroda yang dipasang pada satu atau dua temples pada pelipis. Jumlah tindakan yang dilakukan merupakan rangkaian yang bervariasi pada setiap pasien tergantung pada masalah pasien dan respon terapeutik sesuai hasil pengkajian selama tindakan. Pada pasien Skizofrenia biasanya diberikan 30 kali. ECT biasanya diberikan 3 kali seminggu walaupun biasanya diberikan jarang atau lebih sering. Indikasi penggunaan obat: penyakit depresi berat yang tidak berespon terhadap obat, gangguan bipolar di mana pasien sudah tidak berespon lagi terhadap obat dan pasien dengan bunuh diri akut yang sudah lama tidak mendapatkan pertolongan.

\section{Psikoterapi}


Membantu waktu yang relatif lama, juga merupakan bagian penting dalam proses teraupetik. Upaya dalam psikoterapi ini meliputi : memberikan rasa aman dan tenang, menciptakan lingkungan teraupetik,memotivasi klien untuk dapat mengungkap perasaan secara verbal,bersikap ramah, sopan dan jujur terhadap klien

\subsection{Konsep dasar asuhan keperawatan}

\subsubsection{Pengkajian Keperawatan}

Menurut (Keliat, 2016). Bahwa faktor-faktor terjadinya halusinasi meliputi:

1. Faktor predisposisi

a. Faktor biologis

Pada keluarga yang melibatkan anak kembar dan anak yang diadopsi menunjukkan peran genetik pada schizophrenia. Kembar identik yang dibesarkan secara terpisah mempunyai angka kejadian Schizophrenia lebih tinggi dari pada saudara sekandung yang dibesarkan secara terpisah.

b. Faktor psikologis

Hubungan interpersonal yang tidak harmonis akan mengakibatkan stress dan kecemasan yang berakhir dengan gangguan orientasi realita.

c. Faktor social budaya

Stress yang menumpuk awitan schizophrenia dan gangguan psikotik lain, tetapi tidak diyakini sebagai penyebab utama gangguan.

2. Faktor presipitasi 
b. Biologis

Stressor biologis yang berhubungan dengan respon neurobiologis maladaptif adalah gangguan dalam komunikasi dan putaran umpan balik otak dan abnormalitas pada mekanisme pintu masuk dalam otak, yangmengakibatkan ketidakmampuan untuk secara selektif menanggapi stimulus.

c. Lingkungan

Ambang toleransi terhadap stres yang ditentukan secara biologis berinteraksi dengan stresor lingkungan untuk menentukan terjadinya gangguan prilaku.

d. Stres Social / budaya

Stres dan kecemasan akan meningkat apabila terjadi penurunan stabilitas keluarga, terpisahnya dengan orang terpenting atau disingkirkan dari kelompok.

e. Faktor psikologik

Intensitas kecemasan yang ekstrem dan memanjang disertai terbatasnya kemampuan mengatasi masalah dapat menimbulkan perkembangan gangguan sensori persepsi halusinasi.

f. Mekanisme koping

Perilaku yang mewakili upaya untuk melindungi pasien dari pengalaman yang menakutkan berhubungan dengan respons neurobiologis maladaptif meliputi : regresi, berhunbungan dengan masalah proses informasi dan upaya untuk mengatasi ansietas, yang menyisakan sedikit energi untuk aktivitas seharihari. Proyeksi, sebagai upaya untuk menejlaskan kerancuan persepsi dan menarik diri. 
g. Sumber koping

Sumber koping individual harus dikaji dengan pemahaman tentang pengaruh gangguan otak pada perilaku. Orang tua harus secara aktif mendidik anak-anak dan dewasa muda tentang keterampilan koping karena mereka biasanya tidak hanya belajar dari pengamatan. Disumber keluarga dapat pengetahuan tentang penyakit, finensial yang cukup, faktor ketersediaan waktu dan tenaga serta kemampuan untuk memberikan dukungan secara berkesinambungan.

h. Perilaku halusinasi

Batasan karakteristik halusinasi yaitu bicara teratawa sendiri, bersikap seperti memdengar sesuatu, berhenti bicaraditengah tengah kalimat untuk mendengar sesuatu, disorientasi, pembicaraan kacau dan merusak diri sendiri, orang lain serta lingkungan.

\subsubsection{Diagnosa Keperawatan}

Dengan faktor berhubungan dan batasan karakteristik disesuaikan dengan keadaan yang ditemukan pada tiap-tiap partisipan. Topik yang diteliti yakni kemampuan mengontrol halusinasi dengar (Azizah, Zainuri \& Akbar 2016)

1. Harga diri rendah

2. Isolasi social

3. Halusinasi

\subsubsection{Perencanaan Keperawatan}


Rencana tindakan pada keluarga (Muhit,2016) adalah ;

1. Diskusikan masalah yang dihadap keluarga dalam merawat pasien

2. Berikan penjelasan meliputi : pengertian halusinasi, proses terjadinya halusinasi, jenis halusinasi yang dialami, tanda dan gejala halusinasi, proses terjadinya halusinasi.

3. Jelaskan dan latih cara merawat anggota keluarga yang mengalami halusinasi : menghardik, minum obat, bercakap- cakap, melakukan aktivitas.

4. Diskusikan cara menciptakan lingkungan yang dapat mencegah terjadinya halusinasi.

5. Diskusikan tanda dan gejala kekambuhan

6. Diskusikan pemanfaatan fasilitas pelayanan kesehatan terdekat untuk follow up anggota keluarga dengan halusinasi.

Rencana tindakan keperawatan pada klien dengan diagnosa gangguan persepsi sensori halusinasi meliputi pemberian tindakan keperawatan berupa terapi (Sulah, Pratiwi, \& Teguh. 2016) yaitu :

1. Bantu klien mengenal halusinasinya meliputio isi, waktu terjadi halusinasi, isi, frekuensi, perasaan saat terjadi halusinasi respon klien terhadap halusinasi mengontrol halusinasi dengan cara menghardik.

2. meminum obat secara teratur.

3. Melatih bercakap-cakap dengan orang lain,

4. Menyusun kegiatan terjadwal dan dengan aktifitas

\subsubsection{Implementasi}

Implementasi disesuaikan dengan rencana tindakan keperawatan. Pada situasi nyata sering pelaksanaan jauh berbeda dengan rencana, hal ini terjadi karena perawat belum terbiasa menggunakan rencana tertulis dalam melaksanakan tindakan keperawatan. Sebelum melaksanakan tindakan keperawatan yang sudah direncanakan, perawat perlu 
memvalidasi dengan singkat apakah rencana tindakan masih sesuai dan dibutuhkan klien sesuai dengan kondisinya (here and now). Perawat juga menilai diri sendiri, apakah kemampuan interpersonal, intelektual, tekhnikal sesuai dengan tindakan yang akan dilaksanakan, dinilai kembali apakah aman bagi klien. Setelah semuanya tidak ada hambatan maka tindakan keperawatan boleh dilaksanakan (Aldam, \& Wardani,2019).

Adapun pelaksanaan tindakan keperawatan jiwa dilakukan berdasarkan Strategi Pelaksanaan (SP) yang sesuai dengan masing- masing masalah utama. Pada masalah gangguan sensori persepsi: halusinasi pendengaran, terdapat 2 jenis SP, yaitu SP Klien dan SP Keluarga.SP klien terbagi menjadi SP 1 (membina hubungan saling percaya, mengidentifikasi halusinasi "jenis, isi, waktu, frekuensi, situasi, perasaan dan respon halusinasi", mengajarkan cara menghardik, memasukan cara menghardik ke dalam jadwal; SP 2 (mengevaluasi SP 1, mengajarkan cara minum obat secara teratur, memasukan ke dalam jadwal); SP 3 (mengevaluasi SP 1 dan SP 2, menganjurkan klien untuk mencari teman bicara); SP 4 (mengevaluasi SP 1, SP 2, dan SP 3, melakukan kegiatan terjadwal).

SP keluarga terbagi menjadi SP 1 (membina hubungan saling percaya, mendiskusikan masalah yang dihadapi keluarga dalam merawat pasien, menjelaskan pengertian, tanda dan gejala helusinasi,jenis halusinasi yang dialami klien beserta proses terjadinya, menjelaskan cara merawat pasien halusinasi); SP 2 (melatih keluargamempraktekan cara merawat pasien dengan halusinasi, melatih keluarga melakukan cara merawat langsung kepada pasien halusinasi); SP 3 (membantu keluarga membuat jadwal aktivitas di rumah termasuk minum obat (discharge planing), menjelaskan follow up pasien setelah pulang).

Pada saat akan dilaksanakan tindakan keperawatan maka kontrak dengan klien dilaksanakan dengan menjelaskan apa yang akan dikerjakan dan peran serta klien yang diharapkan, dokumentasikan 
semua tindakan yang telah dilaksanakan serta respon klien.

\subsubsection{Evaluasi Keperawatan}

Evaluasi adalah proses hasil atau sumatif dilakukan dengan membandingkan respon klien pada tujuan umum dan tujuan khusus yang telah ditentukan.halusinasi pendengaran tidak terjadi perilaku kekerasan, klien dapat membina hubungan saling percaya, klien dapat mengenal halusinasinya, klien dapat mengontrol halusinasi dengar dari jangka waktu 4x24 jam didapatkan data subjektif keluarga menyatakan senang karena sudah diajarkan teknik mengontrol halusinasi, keluarga menyatakan pasien mampu melakukan beberapa teknik mengontrol halusinasi (Sulah, Pratiwi, \& Teguh. 2016).

Data objektif :

pasien tampak berbicara sendiri saat halusinasi itu datang, pasien dapat berbincang-bincang dengan orang lain, pasien mampu melakukan aktivitas terjadwal, dan minum obat secara teratur 


\section{BAB 3}

\section{TINJAUAN KASUS}

\subsection{Identitas Klien}

$\begin{array}{ll}\text { Inisial } & : \text { Tn. } \mathrm{R} \\ \text { Tanggal Pengkajian } & : \text { 24 Januari } 2022 \\ \text { Umur } & : \text { 32 Tahun } \\ \text { Agama } & : \text { Islam } \\ \text { No Rm } & : 04.59 .49 \\ \text { Tanggal MRS } & : \text { 13 Desember } 2021\end{array}$

\subsection{Alasan Masuk}

Klien awalnya marah-marah dan melempar barang-barang karena kesel mendengar suara-suara bisikkan ditelinganya sehingga memukul salah satu anggota keluarganya dan sulit tidur. Masalah keperawatan : Gangguan persepsi sensori Halusinasi pendengaran

\subsection{Faktor Predisposisi}

Klien sebelumnya pernah mengalami gangguan jiwa 2 tahun yang lalu tepatnya pada tahun 2018 dan pulang kerumah dalam keadaan tenang. Dirumah klien tidak rutin minum obat, tidak mau kontrol ke RSJ sehingga timbul gejala-gejala sepeti diatas kemudian klien kambuh lagi. Kien awalnya marah-marah dana melempar barang-barang karena kesel, mendengar suara orang membisikkan ditelinganya sehingga memukul orang rumah dan sering mendengar suarasuara mengejek dan sulit tidur akhirnya keluarga membawa klien kembalai di RSJ prof. Dr. Muhammad Ildrem 13 Desember 2021. Keluarga klien tidak ada yang pernah mengamali gangguan jiwa

Masalah keperawatan :

Regimen teraupetik inefektif

Koping invidu tidak efektif

Koping keluarga tidak efektif 


\subsection{Fisik}

Klien tidak memiliki keluhan fisik, saat dilakukan pemeriksaan tanda-tanda vital, didapatkan hasil TD : 106/67 mmHg, HR : 83x/i, RR: 20x/i,S: 36Oc. Klien memiliki tinggi badan $172 \mathrm{~cm}$ dan berat badan $60 \mathrm{~kg}$.

\subsection{Psikososial}

\subsubsection{Genogram}

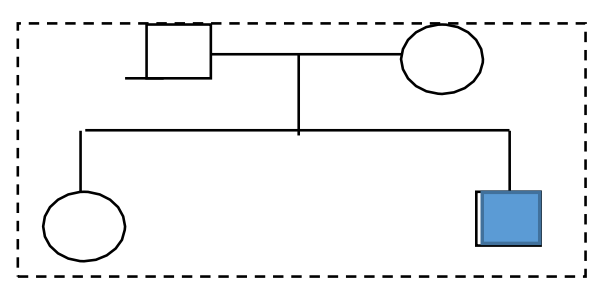

Penjelasan :

klien merupakan anak ke dua dari 2 bersaudara ,klien memiliki satu kakak perempuaan yang sudah menikah

keterangan

: perempuan

: laki-laki

: klien

/ : cerai

$\sqcap$ : garis keturunan

$\sqcup$ : garis perkawinan

:

$\bigotimes$ : meninggal 


\subsubsection{Konsep diri}

1. Gambaran diri $\quad$ : Klien menyukai seluruh tubuhnya dan tidak ada yang cacat

2. Identitas : Klien mengetahui nama dan alamatnya klien merupakan anak ke dua dari 2 bersaudara.

3. Peran : Klien berperan sebagai anak

4. Ideal diri $\quad$ : klien merasa malu klien tidak bisa mengendalikan dirinya sendiri dan merasa putus asa

5. Harga diri : Klien mengatakan tidak mampu mewujudkan impianya, merasa gagal karena tidak mapan dan akhirnya ditinggalkan oleh tunangannya Masalah keperawatan : Gangguan Konsep diri : Harga diri rendah

\subsubsection{Hubungan Sosial}

Klien menggangap bahwa keluarganya adalah orang sangat berarti dalam hidupnya, terutama orang tuanya, klien tidak mengikuti kegiatan kelompok. Klien mengatakan mempunyai hambatan dalam berhubungan dengan orang lain karena sulit bergaul, tidak mau berintraksi dengan orang lain dan selalu ingin menyendiri

Masalah keperawatan : isolasi sosial : menarik diri

\subsubsection{Spiritual}

a. Nilai dan kenyakinan : Klien beragam islam dan yakin dengan agamnya

b. Kegiatan ibadah : Klien tidak ikut melakukan ibadah selama dirawat

\subsubsection{Status Mental}

1. Penampilan : pasien rapi seperti berpakaian biasa pada umumnya

2. Pembicaraan : klien berbicara lambat dan sedikit berkomunikasi

3. Aktivitas motorik : Klien sering mondar-mandir sambil berbicara sendiri, senyum-senyum sendiri

4. Suasana perasaan : klien tidak mampu memgapresikan perasaannya pada saat mendengarkan suara-suara 
5. Afek : afek wajah sesuai dengan topik pembicaraan

6. Interaksi selama wawancara : klien tidak kooperatif, kontak mata kurang saat wawancara

7. Persepsi : klien mengatakan bahwa ia sering mendengar suara-suara mengejek dirinya ketika klien sendiri, klien mendengar suara itu pada saat pagi, siang, dan malam. klien merasa gelisah dan takut

8. Proses pikir : klien mampu menjawab apa yang ditanya

9. Isi pikir : klien dapat mengotrol isi pikirnya, klien tidak mengalami gangguan isi pikir dan tidak masalah

10.Tingkat kesadaran : klien mampu berorientasi, klien mengenali waktu orang dan tempat

11.Memori : Klien mampu menceritakan kejadian di masa lalu dan yang baru terjadi.

12. Tingkat konsentrasi berhitung : Klien mampu berkonsentrasi dalam perhitungan sederhana tanpa bantuan orang lain.

13.Kemampuan : Klien dapat membedakan hal yang baik dan yang buruk (mampu melakukan penilaian)

14.Daya tilik diri : klien tidak mengingkari penyakit yang diderita klien mengetahui bahwa dia sedang sakit dan dirawat dirumah sakit jiwa Masalah keperawatan : gangguan persepsi sensori : Halusinasi pendengaran

\subsection{Mekanisme Koping}

Klien mengalami mekanisme koping adaptif yaitu klien dapat berbicara baik dengan orang lain.

\subsection{Masalah Psikososial Dan Lingkungan}

Klien mengatakan sulit berteman dengan orang lain karena klien selalu ingin menyendiri.

Masalah keperawatan ; isolasi Social ; menarik diri

\subsection{Pengetahuan Kurang Tentang Gagguan Jiwa}

Klien tidak mengetahui tentang gangguan jiwa yang di alaminya dan obat yang dikonsumsinya. 


\subsection{Aspek Medik}

Diagnosa medis : Skizofrenia paranoid

Terapi medis yang diberikan :

1. Resperidone tablet $2 \mathrm{mg} 2 \times 1$

2. Clozapine $25 \mathrm{mg} 1 \mathrm{x} 1$

\subsection{Analisa Data}

\begin{tabular}{|c|c|c|}
\hline No & Data & Masalah keperawatan \\
\hline 1 & $\begin{array}{ll}\text { Ds } & \text { Klien merasa malu karena tidak mapan } \\
\text { - } & \text { Klien merasa malu karena tidak dapat } \\
& \text { mengendalikan dirinya } \\
\text { - } & \text { Klien merasa gagal karena tidak mampu } \\
& \text { mewujudkan impiannya } \\
\text { - } & \text { Klien merasa putus asa karena di tinggalkan } \\
& \text { tunangannya } \\
\text { Do : } & \text { - Klien tampak malu } \\
\text { - Ekpresi wajah kosong } \\
\text { - Kontak mata kurang } \\
\text { - Berbicara lambat dan pelan }\end{array}$ & $\begin{array}{l}\text { Gangguan konsep diri : } \\
\text { harga diri rendah kronis }\end{array}$ \\
\hline 2 & $\begin{array}{l}\text { Ds : } \\
\text { - Klien mengatakan sering mendengarkan } \\
\text { suara suara mengejek dirinya } \\
\text { - Klien mengatakan mendengar suara - suara } \\
\text { tersebut muncul } 3 \text { kali / hari, muncul pada saat } \\
\text { klien sedang menyendiri } \\
\text { - Klien merasa gelisah dan takut jika mendengar } \\
\text { suara tersebut } \\
\text { DO: } \\
\text { - Klien sering mondar - mandir } \\
\text { - Berbicara sendiri } \\
\text { - Sering senyum-senyum sendiri }\end{array}$ & $\begin{array}{l}\text { Gangguan persepsi sensori } \\
\text { : halusinasi pendengaran }\end{array}$ \\
\hline & $\begin{array}{l}\text { Ds : } \\
\text { - Klien mengatakan mempunyai hambatan dalam } \\
\text { berhubungan dengan orang lain }\end{array}$ & Isolasi Sosial : MenarikDiri \\
\hline
\end{tabular}




\begin{tabular}{|l|l|l|}
\hline - Klien mengatakan sulit berteman dengan orang lain & \\
karena klien selalu ingin menyendir & \\
DO : & \\
- Sulit bergaul & \\
- Tidak mau berintraksi dengan orang lain dan & \\
- selalu ingin menyendiri & \\
- Kontak mata kurang & \\
- Tidak mau berinteraksi & \\
\hline
\end{tabular}

\subsection{Masalah Keperawatan}

1. Gangguan Persepsi Sensori : Halusinasi Pendengaran

2. Gangguan Konsep Diri : Harga Diri Rendah

3. Isolasi Sosial: Menarik Diri

\subsubsection{Pohon Masalah}

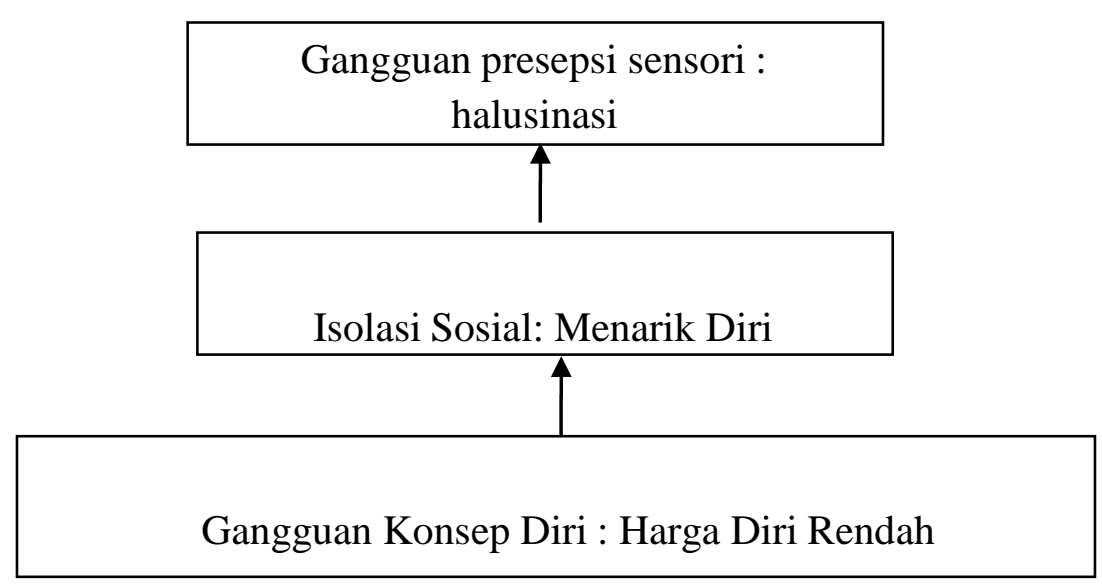

\subsubsection{Prioritas Diagnosa Keperawatan}

Gangguan persepsi Sensorik : Halusinasi pendengaran 


\subsection{Intervensi Keperawatan}

\begin{tabular}{|c|c|c|}
\hline No & Diagnosa & Intervensi \\
\hline 1. & $\begin{array}{l}\text { Gangguan Persepsi Sensori : } \\
\text { Halusinasi Pendengaran } \\
\text { DO: } \\
\text { Klien sering mondar- } \\
\text { mandir } \\
\text { - Berbicara sendiri } \\
\text { - Sering senyum-senyum } \\
\text { sendiri } \\
\text { DS: } \\
\text { - Klien mengatakan } \\
\text { sering } \\
\text { mendengarkan suara } \\
\text { suara mengejek } \\
\text { dirinya } \\
\text { - Klien mengatakan } \\
\text { mendengar suara - suara } \\
\text { tersebut muncul } 3 \text { kali / } \\
\text { hari, muncul pada saat } \\
\text { klien sedang menyendiri } \\
\text { - Klien merasa gelisah dan } \\
\text { takut jika mendengar } \\
\text { suara tersebut } \\
\text { men }\end{array}$ & $\begin{array}{l}\text { SP 1: } \\
\text { 1. Identifikasi isi, waktu } \\
\text { terjadi,situasi pencetus, dan } \\
\text { responterhadap halusinasi } \\
\text { 2. mengontrol halusinasi } \\
\text { dengan cara menghardik } \\
\text { SP 2: } \\
\text { Mengontrol Halusinasi dengan } \\
\text { cara minum obat secara teratur } \\
\text { SP 3: } \\
\text { mengontrol halusinasi dengancara } \\
\text { bercakap - cakap dengan orang } \\
\text { lain } \\
\text { SP 4: } \\
\text { mengontrol halusinasi dengan } \\
\text { cara melakukan aktifitas } \\
\text { terjadwal }\end{array}$ \\
\hline
\end{tabular}




\begin{tabular}{|c|c|c|}
\hline No & Diagnosa & Intervensi \\
\hline 2. & $\begin{array}{l}\text { Isolasi sosial : menarik diri } \\
\text { DO: } \\
\text { - sulit bergaul } \\
\text { - tidak mau berintraksi } \\
\text { dengan orang lain dan } \\
\text { - selalu ingin menyendiri } \\
\text { - Kontak mata kurang } \\
\text { - Tidak mau berinteraksi } \\
\text { DS: } \\
\text { Klien mengatakan tidak } \\
\text { mengikuti kegiatan di } \\
\text { kelompok/masyarakat. } \\
\text { Klien mengatakan } \\
\text { mempunyai hambatan } \\
\text { dalam berhubungan } \\
\text { dengan orang lain karena } \\
\text { klien sulit bergaul dan } \\
\text { selalu ingin menyendiri }\end{array}$ & $\begin{array}{l}\text { SP 1: } \\
\text { Menjelakan keuntungan dan } \\
\text { kerugian memiliki teman } \\
\text { SP 2: } \\
\text { Melatih klien berkenalan dengan } 2 \\
\text { orang atau lebih } \\
\text { SP 3: } \\
\text { Melatih klien bercakap-cakap } \\
\text { sambil melakukan kegiatan harian } \\
\text { SP 4: } \\
\text { Melatih klien berbicara sosial : } \\
\text { seperti meminta sesuat,berbelanja } \\
\text { dan sebagainya }\end{array}$ \\
\hline No & Diagnosa & \\
\hline 3 & $\begin{array}{l}\text { Gangguan konsep diri : } \\
\text { Harga diri rendah } \\
\text { DO: } \\
\text { - Klien tampak malu } \\
\text { - Ekpresi wajah kosong } \\
\text { - Kontak mata kurang } \\
\text { - Berbicara lambat dan } \\
\text { pelan } \\
\text { DS: } \\
\text { - Klien merasa malu } \\
\text { karena tidak mapan } \\
\text { - Klien merasa malu } \\
\text { karena tidak dapat } \\
\text { mengendalikan } \\
\text { dirinya }\end{array}$ & $\begin{array}{l}\text { SP 1: } \\
\text { Mengidentifikasi kemampuan dan } \\
\text { aspek positif yang dimiliki pasien } \\
\text { SP 2: } \\
\text { a. Menilai kemampuan yang } \\
\quad \text { dapat digunakan } \\
\text { b. Menetapkan/memilki kegiatan } \\
\quad \text { sesuai kemampuan } \\
\text { c. Melatih kempuan sesuai } \\
\quad \text { kemampuan yang dipilih } 1 \\
\text { SP 3: } \\
\text { Melatih kemampuan yang dipilih } 2 \\
\text { SP 4: } \\
\text { Melatih kemampuan yang dipilih } 3\end{array}$ \\
\hline
\end{tabular}




\begin{tabular}{|l|l|l|}
\hline - Klien merasa gagal & \\
karena tidak mampu & \\
mewujudkan & \\
impiannya & Klien merasa putus \\
asa karena di & \\
tinggalkan & tunangannya & \\
\hline
\end{tabular}




\subsection{Implementasi dan Evaluasi}

\begin{tabular}{|c|c|c|}
\hline WAKTU & Implemtasi & Evaluasi \\
\hline $\begin{array}{l}\text { Selasa, 25 } \\
\text { januari } 2022 \\
15.00\end{array}$ & 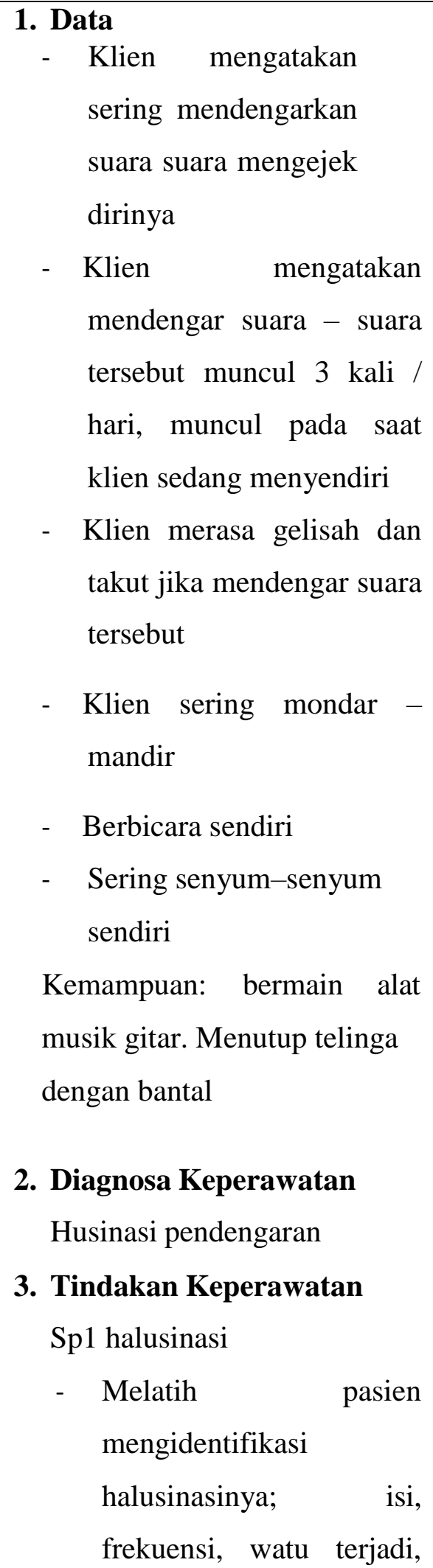 & $\begin{array}{l}\text { S : Klien merasa senang sudah di } \\
\text { bantu dan klien merasa semangat } \\
\text { O : } \\
\text { - Klien mampu mengenali } \\
\text { halusinasi yang dialami nya; isi, } \\
\text { frekuensi, watu terjadi, sruasi } \\
\text { pencetus,perasaan, respon } \\
\text { dengan mandiri } \\
\text { Klien mampu Mengontrol } \\
\text { halusinasinya dengan cara } \\
\text { menghardik dengan bantuan }\end{array}$ \\
\hline
\end{tabular}




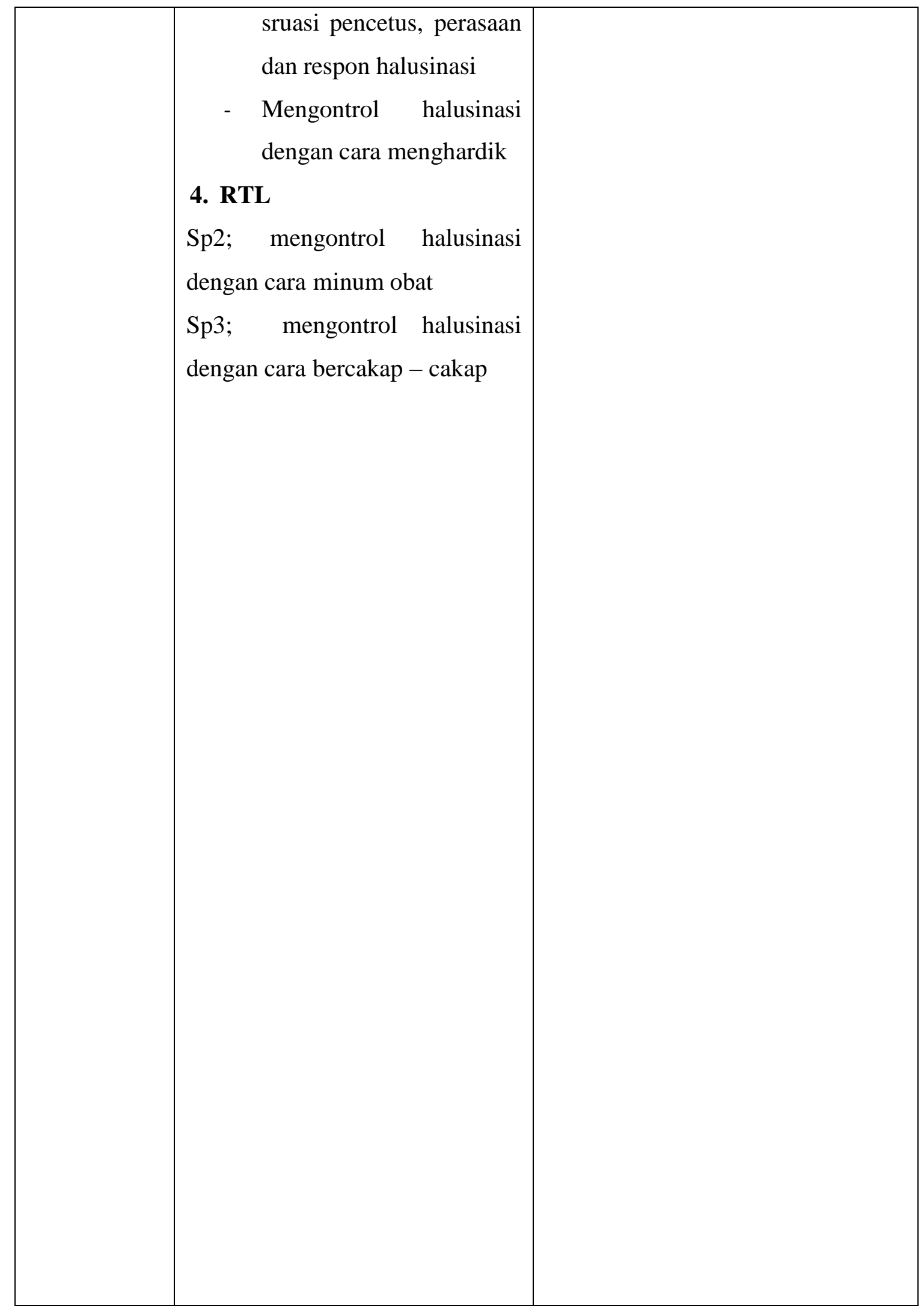




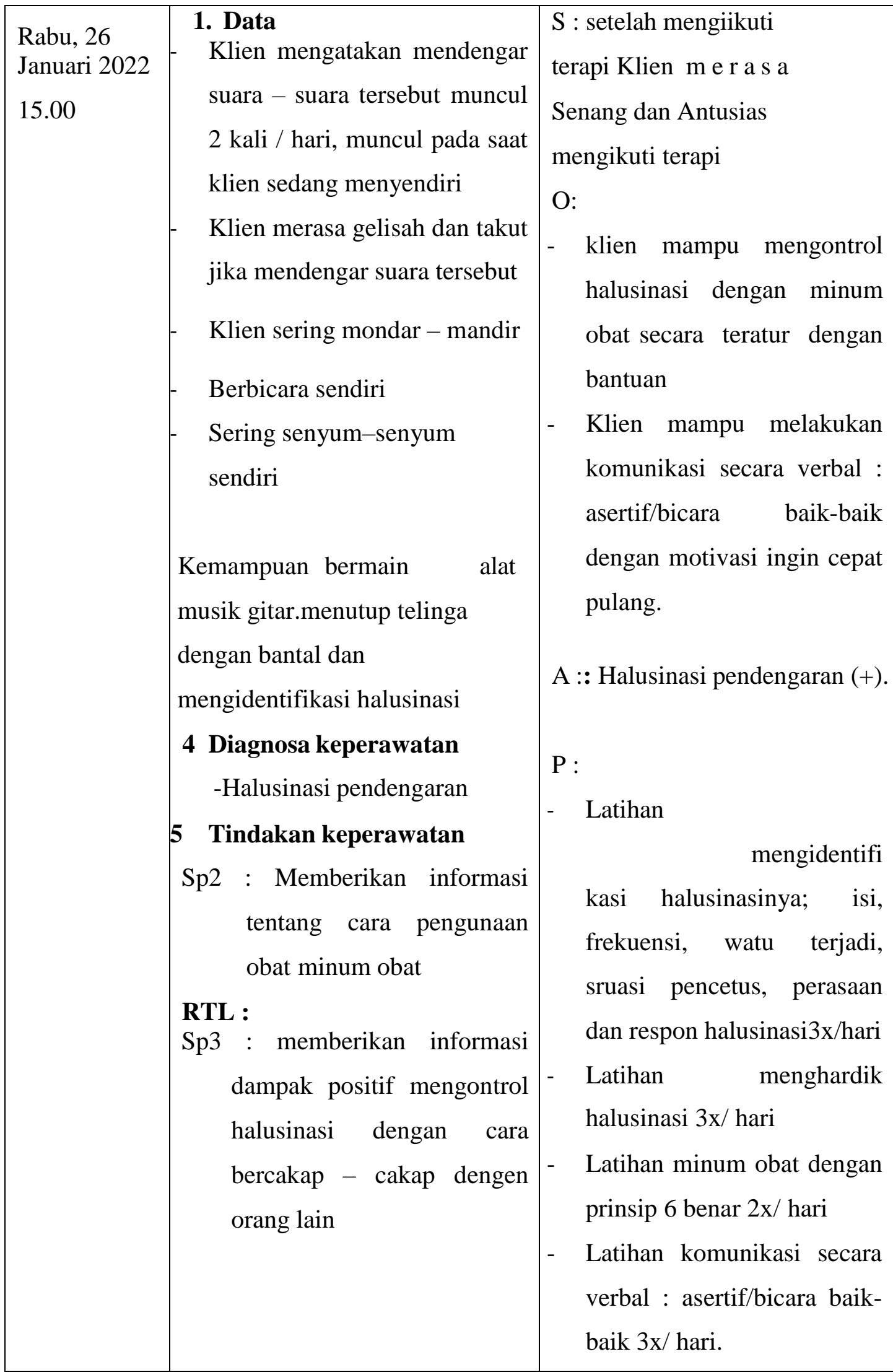




\begin{tabular}{|c|c|c|}
\hline $\begin{array}{l}\text { Kamis, } 27 \\
\text { Januari } 2022 \\
15.00\end{array}$ & $\begin{array}{l}\text { 1. Data } \\
\text { Klien mengatakan mendengar } \\
\text { suara - suara tersebut muncul } \\
1 \text { kali / hari, muncul pada saat } \\
\text { klien sedang menyendiri } \\
\text { dipagi hari sebelum minum } \\
\text { obat } \\
\text { Klien sering mondar - mandir } \\
\text { Berbicara sendiri } \\
\text { Sering senyum-senyum } \\
\text { sendiri } \\
\text { Kemampuan: } \\
\text { musik gitar. } \\
\text { 2. Diagnosa keperawatan } \\
\text { Halusinasi } \\
\text { 3. Tindakan keperawatan } \\
\text { Sp4 : Halusinasi } \\
\text { - Mengevaluasi kemampuan } \\
\text { evaluasi Sp 1-4 Halusinasi } \\
\text { - Menghardik Halusinasi }\end{array}$ & $\begin{array}{l}\text { S: klien mengatakan dia } \\
\text { merasa } \\
\text { senang bisa bercakap-cakap } \\
\text { denganorang lain } \\
\text { O : Klien ma mpu } \\
\text { bercakap-cakap dengan orang } \\
\text { lain secara mandiri } \\
\text { A : Halusinasi pendengaran (+) } \\
\text { P : Intervensi dilanjutkan } \\
\text { - Latihan menghardik } \\
\quad \text { halusinasi } 3 \text { x/ hari } \\
\text { Latihan minum obat } \\
\text { denganprinsip } 6 \text { benar } 2 \\
\text { x/ hari } \\
\text { Latihan bercakap- } \\
\text { cakapdengan orang lain } \\
\text { 3x/ hari } \\
\text { Latihan kegiatan spritual }\end{array}$ \\
\hline
\end{tabular}




\begin{tabular}{|c|c|c|}
\hline & 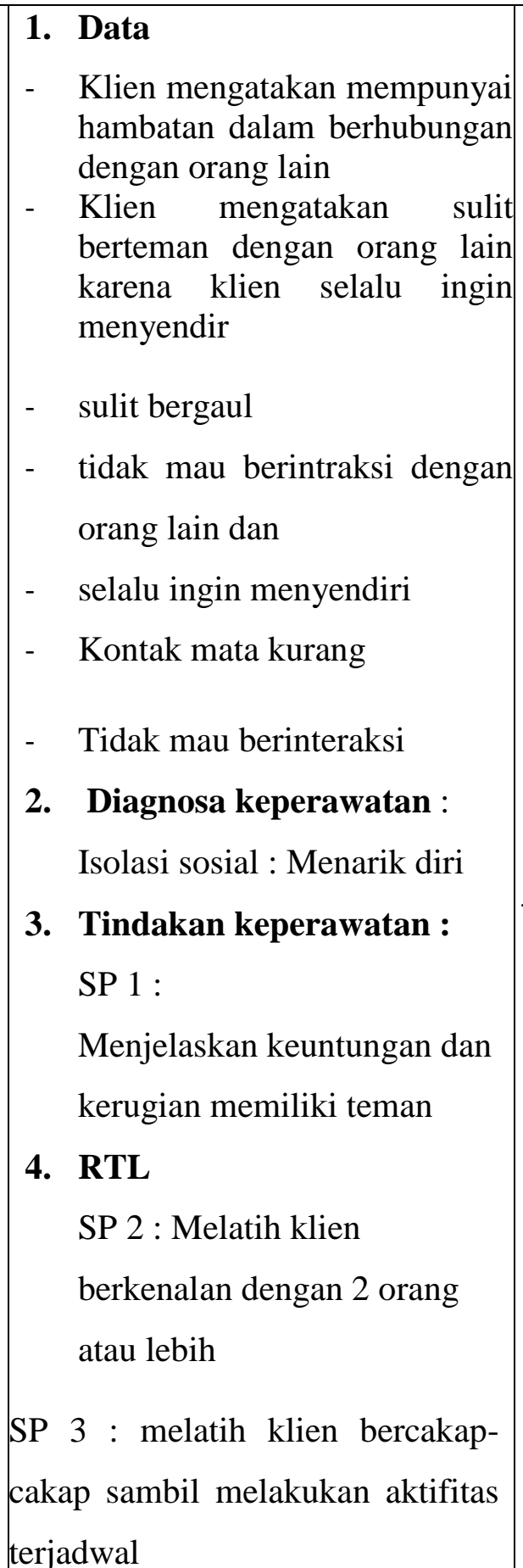 & $\begin{array}{l}\mathrm{S}: \text { Klien merasa senang } \\
\text { sudah mengetahui } \\
\text { keuntungan dan kerugian } \\
\text { mempunyai teman } \\
\text { O : Pasien mampu } \\
\text { memahami keuntungan dan } \\
\text { kerugian memiliki teman } \\
\text { secara mandiri } \\
\text { A: Isolasi Sosial : Menarik } \\
\text { diri (+) } \\
\text { P: } \\
\text { - Menjelaskan keuntungan } \\
\text { dan kerugian memiliki teman } \\
\text { 3x/hari } \\
\text { - Melatih klien berkenalan } 2 \\
\text { orang atau lebih 3x/hari }\end{array}$ \\
\hline
\end{tabular}




\begin{tabular}{|c|c|c|c|}
\hline $\begin{array}{l}\text { Rabu } 2 \text { Febuari } \\
2022\end{array}$ & (B. & $\begin{array}{l}\text { Data } \\
\text { Klien mengatakan } \\
\text { mengetahui keuntungan } \\
\text { dan kerugian memilki } \\
\text { teman mengatakan sulit } \\
\text { Klien men } \\
\text { berteman dengan orang } \\
\text { lain karena klien selalu } \\
\text { ingin menyendir } \\
\text { sulit bergaul } \\
\text { tidak mau berintraksi } \\
\text { dengan orang lain dan } \\
\text { selalu ingin menyendiri } \\
\text { Kontak mata kurang } \\
\text { Tidak mau berinteraksi }\end{array}$ & $\begin{array}{l}\text { S: setelah mengiikuti } \\
\text { terapi klien m e r a s a } \\
\text { Senang dan Antusias } \\
\text { mengikuti terapi } \\
\text { O: Kien mampu } \\
\text { berkenalan dengan } 2 \\
\text { orang atau lebih dengan } \\
\text { mandiri } \\
\text { A : Isolasi sosial : Menarik } \\
\text { diri (+) } \\
\text { P : } \\
\text { - Melatih klien } \\
\quad \text { berkenalan dengan } 2 \\
\quad \text { orang atau lebih } 3 x / h a r i \\
\text { - Melatih klien bercakap- } \\
\text { cakpa sambil } \\
\text { melakukan aktivitas } \\
\text { harian } 3 x / \text { hari }\end{array}$ \\
\hline
\end{tabular}




\begin{tabular}{|c|c|c|c|}
\hline & 1. & $\begin{array}{l}\text { Data } \\
\text { Klien mengatakan } \\
\text { mengetahui keuntungan } \\
\text { dan kerugian memilki } \\
\text { teman mengatakan sulit } \\
\text { Klien selalu } \\
\text { berteman dengan orang } \\
\text { lain karena klien } \\
\text { ingin menyendir } \\
\text { sulit bergaul } \\
\text { tidak mau berintraksi } \\
\text { dengan orang lain dan } \\
\text { selalu ingin menyendiri } \\
\text { Kontak mata kurang } \\
\text { Tidak mau berinteraksi } \\
\text { Diagnosa keperawatan : } \\
\text { Isolasi sosial : Menarik } \\
\text { diri } \\
\text { Tindakan } \\
\text { keperawaatan : } \\
\text { SP } 3 \text { : Melatih klien } \\
\text { bercakap-cakap sambil } \\
\text { melakukan aktivitas } \\
\text { harian } \\
\text { Rtl : } \\
\text { derbicara sosial : } \\
\text { meminta sesuatu, belanja } \\
\text { dan sebagainya }\end{array}$ & $\begin{array}{l}\text { S : klien merasa senang } \\
\text { bisa bercakap-cakap } \\
\text { sambil melakukan } \\
\text { kegiatan harian } \\
\text { O : klien mampu } \\
\text { bercakap-cakap sambil } \\
\text { melakukan aktivitas } \\
\text { harian dengan mandiri } \\
\text { A: Isolasi sosial : Menarik } \\
\text { diri (+) } \\
\text { P : Intervensi lanjutan } \\
\text { - } \quad \text { Melatih klien } \\
\quad \text { berkenalan dengan } 2 \\
\quad \text { orang atau lebih } 3 x / h a r i \\
\text { - Melatih klien bercakap- } \\
\text { cakap sambil } \\
\text { melakukan aktivitas } \\
\text { harian } 3 x / h a r i \\
\text { - Melatih klien berbicara } \\
\text { sosial : meminta } \\
\text { sesuatu, belanja dan } \\
\text { sebagainya }\end{array}$ \\
\hline
\end{tabular}




\begin{tabular}{|c|c|c|c|}
\hline & \multicolumn{2}{|c|}{$\begin{array}{l}\text { 1. Data } \\
\text { Sudah berbicara dengan } \\
\text { teman sekamar } \\
\text { 2. Diagnosa keperawatan : } \\
\text { Isolasi sosial : Menarik } \\
\text { diri } \\
\text { 3. Tindakan } \\
\text { keperawaatan : } \\
\text { SP 4: Melatih klien } \\
\text { berbicara sosial : } \\
\text { meminta sesuatu, belanja } \\
\text { dan sebagainya }\end{array}$} & $\begin{array}{l}\text { S : Klien mengatakan } \\
\text { senang sudah mampu } \\
\text { bercakap dan berbicara } \\
\text { sosial kepada teman } \\
\text { sekamar } \\
\text { O: klien mampu } \\
\text { berbicara sosial meminta } \\
\text { tolong dengan mandiri } \\
\text { A: Isolasi sosial : } \\
\text { Menarik diri (+) } \\
\text { P : Intervensi lanjutan } \\
\text { - Melatih klien } \\
\quad \text { berkenalan dengan } 2\end{array}$ \\
\hline
\end{tabular}




\begin{tabular}{|c|c|c|}
\hline & 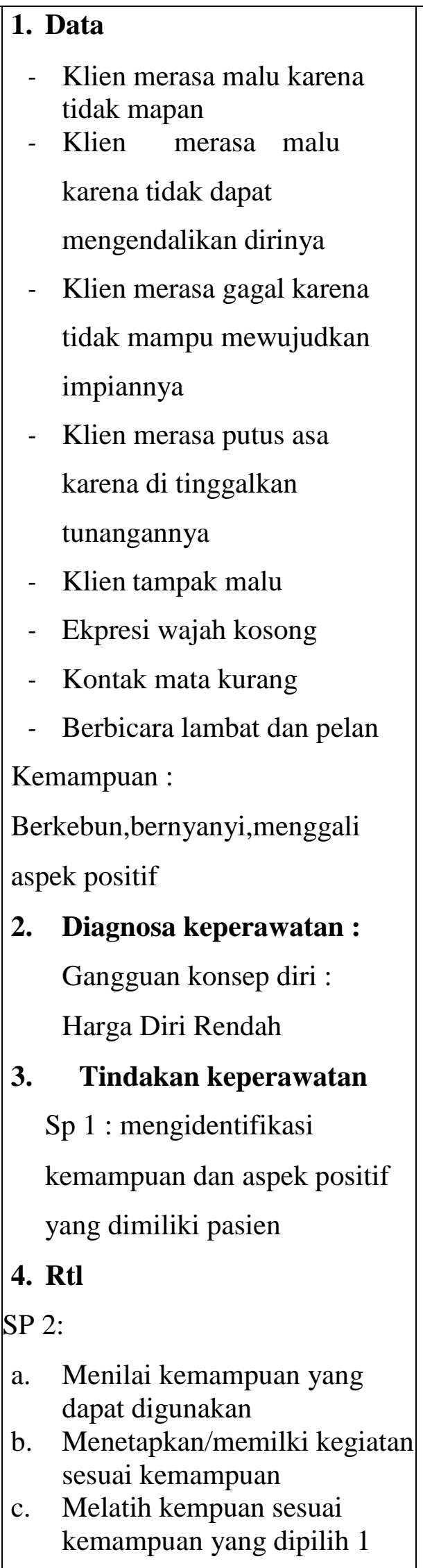 & $\begin{array}{l}\text { S: klien senang sudah } \\
\text { bisa menggali aspek } \\
\text { positif } \\
\text { O : Klien mengatakan } \\
\text { mampu mengidentifikasi } \\
\text { aspek positif dengan } \\
\text { mandiri } \\
\text { A: Gangguan konsep diri : } \\
\text { Harga Diri Rendah (+) } \\
\text { P : } \\
\text { - Latihan mengidentifikasi } \\
\text { kemampuan dan aspek } \\
\text { postif yang dimiliki } \\
\text { sebanyak 3x/hari } \\
\text { - Latihan Menilai } \\
\text { kemampuan yang dapat } \\
\text { digunakan 3x/hari } \\
\text { - Latihan } \\
\text { Menetapkan/memilki } \\
\text { kegiatan sesuai } \\
\text { kemampuan } 3 x / h a r i \\
\text { - Melatih kempuan sesuai } \\
\text { 3x/hari } \\
\end{array}$ \\
\hline
\end{tabular}




\begin{tabular}{|c|c|c|}
\hline & $\begin{array}{l}\text { 1. Data } \\
\text { - Klien merasa malu karena tidak } \\
\text { mapan } \\
\text { - Klien merasa gagal karena } \\
\text { tidak mampu mewujudkan } \\
\text { impiannya } \\
\text { - Klien merasa putus asa karena } \\
\text { di tinggalkan tunangannya } \\
\text { - Klien tampak malu } \\
\text { Kemampuan : } \\
\text { Berkebun,bernyanyi,mengali } \\
\text { aspek positif ,memilih kempuan } \\
\text { 2. Diagnosa keperawatan : } \\
\text { Gangguan konsep diri : } \\
\text { Harga Diri Rendah } \\
\text { 3. Tindakan keperawatan } \\
\text { Sp } 2 \text { : } \\
\text { a. Menilai kemampuan yang } \\
\text { dapat digunakan } \\
\text { Menetapkan/memilki } \\
\text { kegiatan sesuai } \\
\text { kemampuan } \\
\text { Melatih kempuan sesuai } \\
\text { dipilih } 2 \\
\text { 4. Rtl } \\
\text { semampuan yang dipilih } 1 \\
\text {. }\end{array}$ & $\begin{array}{l}\text { S: klien mengatakan } \\
\text { sudah tidak malu karena } \\
\text { sudah memiliki } \\
\text { kemampuan positif } \\
\text { O: } \\
\text { - } \quad \text { klien sudah mampu } \\
\quad \text { mengidentifikasi } \\
\quad \text { kemampuan positif } \\
\text { - } \quad \text { Klien sudah mampu } \\
\quad \text { menilai kemapuan } \\
\quad \text { yang digunakan } \\
\text { Klien sudah mampu } \\
\quad \text { menetapkan } \\
\quad \text { keampuan } \\
\text { A: Gangguan konsep } \\
\text { diri : Harga Diri Renda } \\
\text { (+) } \\
\text { Patih kemampuan yang } \\
\text { dipilih } 2 \text { (3x/hari) } \\
\text { yang dipilih } 1 \text { (3x/hari) }\end{array}$ \\
\hline
\end{tabular}




\begin{tabular}{|c|c|c|}
\hline $\begin{array}{l}\text { Rabu, } 09 \\
\text { febuari } 2022\end{array}$ & $\begin{array}{l}\text { 1. } \text { Data } \\
\text { - } \text { Klien merasa malu karena } \\
\text { tidak mapan } \\
\text { - } \text { Klien merasa gagal karena } \\
\text { tidak mampu mewujudkan } \\
\text { impiannya } \\
\text { - } \quad \text { Klien tampak malu } \\
\text { - } \quad \text { Ekpresi wajah kosong } \\
\text { Kemampuan : } \\
\text { Berkebun,bernyanyi,mengali } \\
\text { aspek positif ,memilih } \\
\text { kemampuan,bermain gitar } \\
\text { 2. Diagnosa keperawatan : } \\
\text { Gangguan konsep diri : } \\
\text { Harga Diri Rendah } \\
\text { 3. Tindakan keperawatan } \\
\text { SP } 3 \text { : Melatih kemampuan } \\
\text { sesuai kemampuan yang } \\
\text { dipilih } 2 \\
\text { 4. Rtl }\end{array}$ & $\begin{array}{l}\text { S: klien mengatakan } \\
\text { senang sudah mampu } \\
\text { melatih kegiatan bermain } \\
\text { gitar } \\
\text { O: } \\
\text { - Klien sudah mampu } \\
\text { melatih kegiatan } \\
\text { bermain gitar } \\
\text { - klien sudah mampu } \\
\text { melatih bergambar } \\
\text { A: Gangguan konsep } \\
\text { diri : Harga Diri Renda } \\
\text { (+) } \\
\text { P : } \\
\text { - Latih kemampuan } \\
\text { yang dipilih } 2 \text { bermain } \\
\text { gitar ( } 2 x / h a r i) \\
\text { Latih kemampuan } \\
\text { yang dipilih } 3 \\
\text { (mengambar) ( } 3 x / h a r i)\end{array}$ \\
\hline
\end{tabular}




\begin{tabular}{|c|c|c|}
\hline $\begin{array}{l}\text { Senin } 14 \\
\text { febuari } 2022\end{array}$ & $\begin{array}{l}\text { 1. Data } \\
\text { - Kontak mata sudah baik } \\
\text { Tampak semangat dengan } \\
\text { kegitan yang diberi } \\
\text { - Klien sudah merasa tidak malu } \\
\text { karena sudah memiliki } \\
\text { kemampuan } \\
\text { Kemampuan : } \\
\text { Berkebun,bernyanyi,mengali } \\
\text { aspek positif ,memilih } \\
\text { kemampuan,bermain } \\
\text { gitar,mengambar } \\
\text { 2. Diagnosa keperawatan : } \\
\quad \text { Gangguan konsep diri : } \\
\quad \text { Harga Diri Rendah } \\
\text { 3. Tindakan keperawatan } \\
\quad \text { SP 4: Melatih kemampuan } \\
\text { sesuai kemampuan yang } \\
\text { dipilih } 3 \\
\text { 4. Rtl } \\
\text { Gangguan konsep diri :Harga diri } \\
\text { rendah Follow up dan evaluasi Sp } \\
\text { 1-4 Harga diri rendah }\end{array}$ & 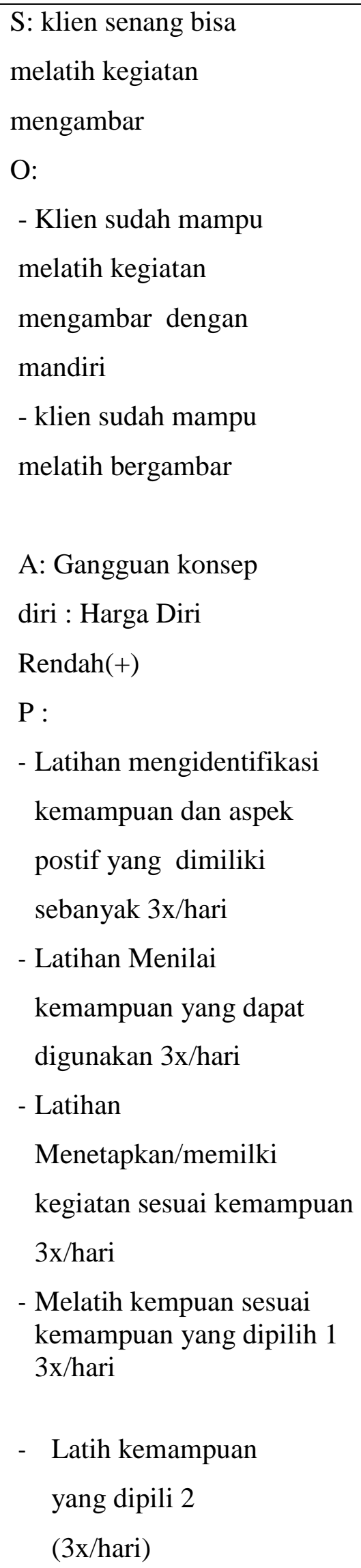 \\
\hline
\end{tabular}




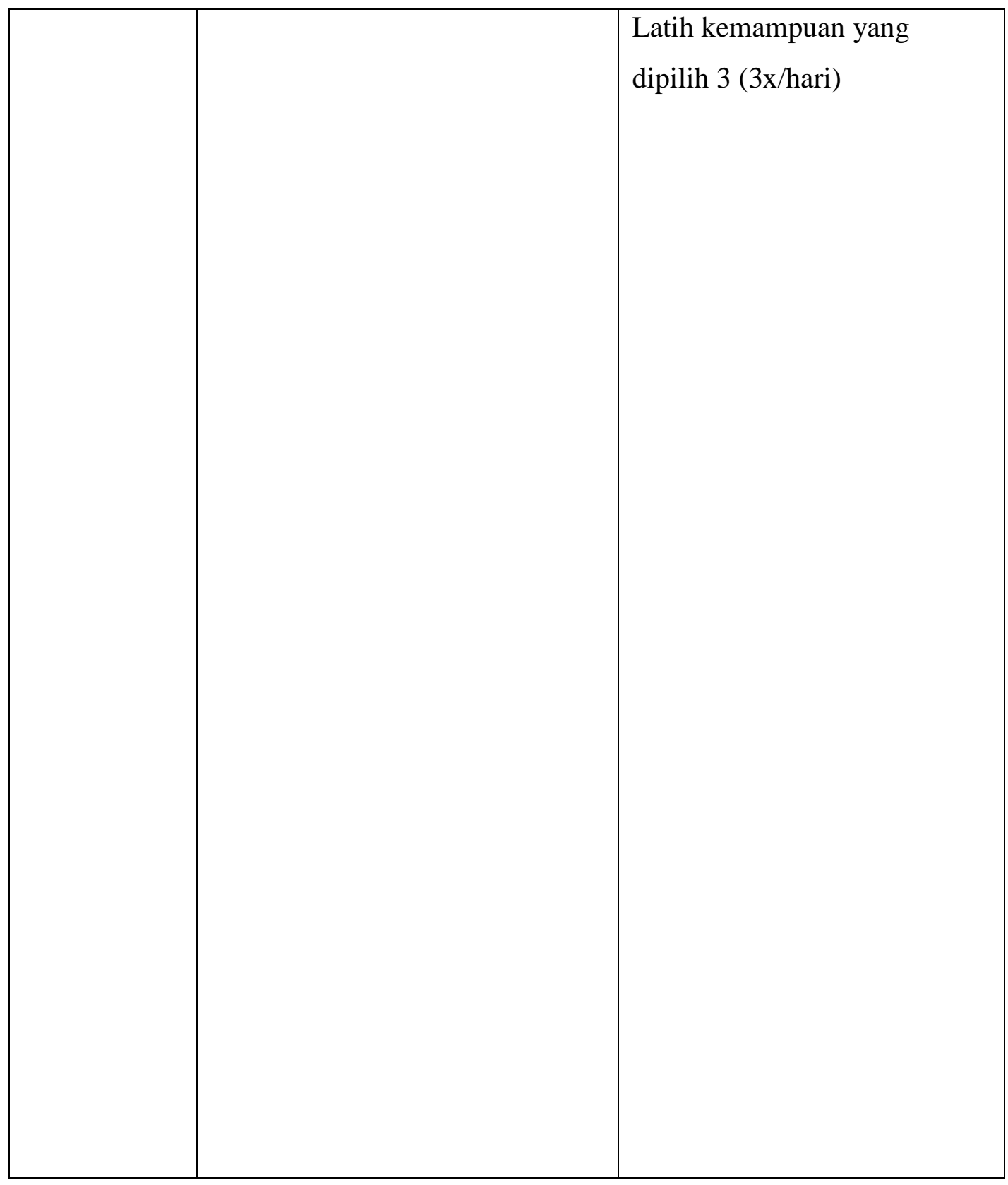




\section{BAB 4 \\ PEMBAHASAN}

Setelah penulis melaksanakan asuhan keperawat kepada Tn.R dengan gangguan sensori persepsi: halusinasi pendengaran Di RSJ prof. Dr. Muhammad Ildrem, maka penulis pada $\mathrm{BAB}$ ini akan membahasan kesenjangan antara teoritis dengan tinjauan kasus. Pembahasan dimulai melalui tahapan proses keperawatan yaitu pengkajian, diagnosa keparawatan, perencanaan, pelaksanaan dan evaluasi.

\subsection{Pengkajian}

Pada pembahasan ini diuraikan tentang hasil pelaksanaan tindakan keperawatan dengan pemberian terapi generalis pada klien halusinasi pendengaran. Pembahasan menyangkut analisis hasil penerapan terapi generalis terhadap masalah keperawatan halusinasi pendengaran. Tindakan keperawatan didasarkan pada pengkajian dan diagnosiskeperawatan yang terdiri dari tindakan generalis yang dijabarkan sebagai berikut.

Tahap pengkajian pada klien halusinasi dilakukan interaksi perawat-klien melalui komunikasi terapeutik untuk mengumpulkan data dan informasi tentang status kesehatan klien. Pada tahap ini terjadi proses interaksi manusia, komunikasi, transaksi dengan peran yang ada pada perawat sebagaimana konsep tentang manusia yang bisa dipengaruhi dengan adanya proses interpersonal.

Selama pengkajian dilakukan pengumpulan data dari beberapa sumber, yaitu dari pasien dan tenaga kesehatan di ruangan. Penulis mendapat sedikit kesulitan dalam menyimpulkan data karena keluarga pasien jarang mengunjungi pasien di rumah sakit jiwa. Maka penulis melakukan pendekatan kepada pasien melalui komunikasi terapeutik yang lebih terbuka membantu pasien untuk memecahkan perasaannya dan juga melakukan observasi kepada pasien. 
Adapun upaya tersebut yaitu:

a. Melakukan pendekatan dan membina hubungan saling percaya diri pada klien agar klien lebih terbuka dan lebih percaya denganmenggunakan perasaan.

b. Mengadakan pengkajian klien dengan wawancara

c. Mengadakan pengkajian dengan cara membaca status, melihat buku rawatan dan bertanya kepada pegawai ruangan Bukit barisan.

Dalam pengkajian ini, penulis menemukan kesenjangan karena ditemukan. Pada kasus Tn.R, klien mendengar suara-suara yang menyuruh untuk melakukan sholat, gelisah, mondar-mandir, tampak tegang, putus asa, sedih dan lain-lain. Gejala gejala yang muncul tersebut tidak semua mencakup dengan yang ada di teori klinis dari halusnasi (Keliat,.2016). Akan tetapi terdapat faktor predisposisi maupun presipitasi yang menyebabkan kekambuhan penyakit yang dialami oleh Tn.R.

Tindakan keperawatan terapi generalis yang dilakukan pada Tn.R adalah strategi pertemuan pertama sampai pertemuan empat. Strategi pertemuan pertama meliputi mengidentifikasi isi, frekuensi, jenis, dan respon klien terhadap halusinasi serta melatih cara menghardik halusinasi. Strategi pertemuan kedua yang dilakukan pada Tn.R meliputi melatih cara mengendalikan dengan bercakap-cakap kepada orang lain. Strategi pertemuan yang ketiga adalah menyusun jadwal kegiatan bersama-samadengan klien. Strategi pertemuan keempat adalah mengajarkan dan melatih Tn.R cara minum obat yang teratur.

\subsection{Diagnosa Keperawatan}

Pada Teori menurut NANDA 2018-2020 diagnosa keperawatan yang muncul sebanyak 3 diagnosa keperawatan yang meliputi:

4. Harga diri rendah

5. Isolasi social

6. Halusinasi

Sedangkan pada kasus Tn.R ditemukan lima diagnosa keperawatan yang 
muncul yang meliputi: harga diri rendah, isolasi sosial, halusinasi, koping individu inefektif, regimen teraupetik inefektif. Dari hal tersebut di atas dapat dilihat terjadi kesamaan antara teori dan kasus. Dimana semua diagnosa pada teori muncul pada kasus Tn.R

\subsection{Intervensi Keperawatan}

Perencanaan dalam proses keperawatan lebih dikenal dengan rencana asuhan keperawatan yang merupakan tahap selanjutnya setelah pangkajian dan penentuan diagnosa keperawatan. Pada tahap perencanaan penulis hanya menyusun rencana tindakan keperawatan sesuai dengan pohon masalah keperawatan yaitu : Gangguan persepsi sensori : Halusinasi pendengaran (Kelliat 2016).

Pada tahap ini antara tinjauan teoritis dan tinjaun kasus tidak ada kesenjangan sehingga penulis dapat melaksanakan tindakan seoptimal mungkin dan didukung dengan tersedianya sarana ruangan perawat yang baik dan adanya bimbingan dan petunjuk dari petugas kesehatan dari rumah sakit jiwa yang diberikan kepada penulis.Secara teoritis digunakan cara strategi pertemuan sesuai dengan diagnosa keperawatan yang muncul saat pengkajian. Adapun upaya yang dilakukan penulis yaitu :

1. Gangguan persepsi sensori : Halusinasi

a. Identifikasi isi, waktu terjadi,situasi pencetus, dan responterhadap halusinasi

b. mengontrol halusinasidengan cara menghardik

c. Mengontrol Halusinasi dengan cara minum obat secara teratur

d. mengontrol halusinasi dengancara bercakap - cakap dengan orang lain

e. Mengontrol halusinasi dengan cara melakukan aktifitas terjadwal

1. Isolasi Sosial: Menarik Diri

a. Menjelaskan keuntungan dan kerugian memiliki teman

b. Melatih klien berkenalan dengan dua orang atau lebih

c. Melatih klien bercakap-cakap sambil melakukan kegiatan harian

d. Melatih berbicara sosial : seperti berbelanja meminta sesuatu 
2. Gangguan konsep diri : Harga diri rendah
a. Mengidentifikasi kemampuan dan aspek positif yang dimiliki pasien
b. Menilai kemampuan yang dapat digunakan
c. Menetapkan/memilki kegiatan sesuai kemampuan
d. Melatih kempuan sesuai kemampuan yang dipilih 1
e. Melatih kemampuan sesuai kemampuan yang dipilih 2
f. Melatih kemampuan sesuai kemampuan yang dipilih 3

\subsection{Implementasi Keperawatan}

Implementasi, adalah tahap dimana perawat memulai melakukan tindakan penulis hanya mengatasi masalah keperawatan halusinasi pendengaran (Aldam, \& Wardani,2019). Dengan melakukan strategi pertemuan yaitu mengidentifikasi isi, frekuensi, waktu terjadi, perasaan, respon halusinasi. Kemudian strategi pertemuan yang dilakukan yaitu latihan mengontrol halusinasi dengan cara menghardik. Strategi pertemuan yang kedua yaitu anjurkan minum obat secara teratur, strategi pertemuan yang ke tiga yaitu latihan dengan cara bercakap - cakap pada saat aktivitas dan latihan strategi pertemuan ke empatyaitu melatih klien melakukankegiatan terjadwal.

\subsection{Evaluasi}

Pada tinajauan teoritis evaluasi yang diharapkan adalah: Pasien mempercayai perawat sebagai terapis, pasien menyadari bahwa yang dialaminya tidak ada objeknya, dapat mengidentifikaasi halusinasi, dapat mengendalikan halusinasi melalui mengahrdik, latihan bercakap-cakap, melakukan aktivitas serta menggunakan obat secara teratur (Sulah, Pratiwi, \& Teguh. 2016).

Pada tinjauan kasus evaluasi yang didapatkan adalah: Klien mampu mengontrol dan mengidentifikasi halusinasi, Klien mampu melakukan latihan bercakap-cakap dengan orang lain, Klien mampu melaksanakan jadwal yang telah dibuat bersama, Klien mampu memahami penggunaan obat yang benar: 5 benar. Selain itu, dapat dilihat dari setiap evalusi yang dilakukan pada asuhan keperawatan, dimana terjadi penurunan gejala yang dialami oleh Tn.R dari hari kehari selama proses interaksi. 


\section{BAB 5}

\section{PENUTUP}

\subsection{Kesimpulan}

Berdasarkan uraian pada pembahasan di atas, maka penulis dapat disimpulkan bahwa:

1. Pengkajian dilakukan secara langsung pada klien dan juga dengan menjadikan status klien sebagai sumber informasi yang dapat mendukung data-data pengkajian. Selama proses pengkajian, perawat mengunakan komunikasi terapeutik serta membina hubungan saling percaya antara perawat-klien. Pada kasus Tn.R, diperoleh bahwa klienmengalami gejalagejala halusinasi seperti mendengar suara-suara, gelisah, sulit tidur, tampak tegang, mondar-mandir,tidak dapat mempertahankan kontak mata, sedih, malu, putus asa, menarik diri, mudah marah dan lain-lain. Faktor predisposisi pada Tn.R yaitu pernah mengalami gangguan jiwa sebelumnya serta memiliki riwayat mengonsumsi alkohol dan obat terlarang.

2. Diagnosa keperawatan yang muncul pada kasus Tn.R:Halusinasi pendengaran, isolasi sosial, koping individu inefektif, regimen teraupetik inefektif keluarga inefektif, harga diri rendah serta keputusasaan. Tetapi pada pelaksanaannya, penulis fokus pada masalah utama yaitu halusinasi pendengaran.

3. Perencanaan dan implementasi keperawatan disesuaikan dengan strategi pertemuan pada pasien halusinasi pendengaran dan harga diri.

4. Evaluasi diperoleh bahwa terjadi peningkatan kemampuan klien dalam mengendalikan halusinasi yang dialami serta dampak pada penurunan gejala halusinasi pendengaran yang dialami. 


\subsection{Saran}

1. Bagi Perawat

Diharapkan dapat menerapkan komunikasi terapeutik dalam pelaksanaan strategi pertemuan 1-4 pada klien dengan halusinasi sehingga dapat mempercepat proses pemulihan klien.

2. Bagi Institusi Pendidikan

Dapat meningkatkan bimbingan klinik kepada mahasiswa profesi ners sehingga mahasiswa semakin mampu dalam melakukan asuhan keperawatan pada pasien-pasien yang mengalami halusinasi pendengaran

3. Bagi Rumah Sakit

Laporan ini diharapkan dapat menjadai acuan dan referensi dalam memberikan asuhan keperawatan pada klien dengan halusinasi pendengaran. 


\section{DAFTAR PUSTAKA}

1. Ali, N. A. M. (2019). Faktor-Faktor Penyebab Penyakit Skizofrenia: Satu Kajian Kes the Causes of Schizophrenia: a Case Study. Jurnal Sains Sosial@Malaysian Journal of Social Sciences, Jilid 4(January), 68-79.

2. Aldam, S. F. S., \& Wardani, I. Y. (2019). Efektifitas penerapan standar asuhan keperawatan jiwa generalis pada pasien skizofrenia dalam menurunkan gejala halusinasi. Jurnal Keperawatan Jiwa (JKJ): Persatuan Perawat Nasional Indonesia, 7(2), 165-172.

3. Abdurkhman, R. N., \& Maulana, M. A. (2022). Psikoreligius Terhadap Perubahan Persepsi Sensorik Pada Pasien Halusinasi Pendengaran Di Rsud Arjawinangun Kabupaten Cirebon. Jurnal Education And Development, 10(1), 251-253.

4. Andri, J., Febriawati, H., Panzilion, P., Sari, S. N., \& Utama, D. A. (2019). Implementasi keperawatan dengan pengendalian diri klien halusinasi pada pasien skizofrenia. Jurnal Kesmas Asclepius, 1(2), 146-155.

5. Hairani, H., Kurniawan, K., Abd Latif, K., \& Innuddin, M. (2021). Metode Dempster-Shafer untuk Diagnosis Dini Jenis Penyakit Gangguan Jiwa Skizofrenia Berbasis Sistem Pakar. Sistemasi: Jurnal Sistem Informasi, 10(2), 280-289.

6. Fatturahman, W ,Putri \& Fradianto 2021, Hubungan Dukungan Keluarga Dengan Tingkat Kepatuhan Minum Obat Pada Pasien Gangguan Jiwa Skizofrenia: Literature Review. Tanjungpura Journal of Nursing Practice and Education, 3(2).

7. Pardede, J. A., \& Ramadia, A. (2021). The Ability to Interact with Schizophrenic Patients through Socialization Group Activity Therapy. International Journal of Contemporary Medicine 1 (1), 06-10 6.

8. Pardede, J. A., Siringo-ringo, L. M., Hulu, T. J., \& Miranda, A. (2021). Edukasi Kepatuhan Minum Obat Untuk Mencegah Kekambuhan Orang Dengan Skizofrenia. Jurnal Abdimas Mutiara, 2(2), 1-5. 7.

9. Pardede, J. A., Keliat, B. A., \& Wardani, I. Y. (2013). Pengaruh Acceptance And Commitment Therapy Dan Pendidikan Kesehatan Kepatuhan Minum Obat Terhadap Gejala, Kemampuan Berkomitmen Pada Pengobatan Dan Kepatuhan Pasien Skizofrenia. FIK UI, Depok. 
10. Pardede, J. A., \& Siregar, R. A. (2016). Pendidikan Kesehatan Kepatuhan Minum Obat Terhadap Perubahan Gejala Halusinasi Pada Klienskizofrenia. Mental Health, 3(1).

11. Pardede, J. A. (2020). Beban Keluarga Berhubungan Dengan Koping Saat Merawat Pasien Halusinasi. Jurnal Ilmu Keperawatan Jiwa, 3(4), 445-452.

12. Pardede, J. A., Simanjuntak, G. V., \& Laia, R. (2020). The Symptoms of Risk of Violence Behavior Decline after Given Prgressive Muscle Relaxation Therapy on Schizophrenia Patients. Jurnal Ilmu Keperawatan Jiwa, 3(2), 91-100.

13. Pardede, J. A. (2020). Decreasing Hallucination Response Through Perception Stimulation Group Activity Therapy In Schizophrenia Patients. Iar Journal of Medical Sciences, 1(6), 304-309. doi: 10.47310/iarjms.2020.v01i06.006

14. Pardede, J. A., Silitonga, E., \& Laia, G. E. H. (2020). The Effects of Cognitive Therapy on Changes in Symptoms of Hallucinations in Schizophrenic Patients. Indian Journal of Public Health, 11(10), 257.

15. Pardede, J. A., Damanik, R. K., Simanullang, R. H., \& Sitanggang, R. (2020). The Effect Of Cognitive Therapy On Changes In Self-Esteem On Schizophrenia Patients. European Journal of Molecular \& Clinical Medicine, 7(11).

16. Riskesdes (2018) Riskesdes Skizofrenia https://www.who.int/newsroom/fact-sheets/detail/schizophrenia. Di unduh Tanggal 24 Januari 2022

17. Stuart. Gail. W, Keliat. Budi. Anna,\& Pasaribu. Jesika.(2016). Keperawatan keseha111tan jiwa: Indonesia : Elsever.

18. Maulana, I., Hernawati, T., \& Shalahuddin, I. (2021). Pengaruh terapi aktivitas kelompok terhadap penurunan tingkat halusinasi pada pasien skizofrenia: literature review. Pengaruh Terapi Aktivitas Kelompok Terhadap Penurunan Tingkat Halusinasi Pada Pasien Skizofrenia: Literature Review, 9(1), 153-160.

19. Try Wijayanto, W., \& Agustina, M. (2017). Efektivitas Terapi Musik Klasik Terhadap Penurunan Tanda dan Gejala pada Pasien Halusinasi Pendengaran. Jurnal Ilmu Keperawatan Indonesia, 7(1), 189-196. 
20. Dermawan. Deden (2018). Modul Keperawatan Jiwa : Gosyen Publishing.

21. Manulang Elis. Melina. Manik. Emma Pratiwi, Monalisa. Teuku. Hamdi \& Tarigan. Shintiya Putri.(2019) Terapi Aktivitas Kelompok Stimulasi Persepsi Pada Pasien Halusinasi Di Yayasan Pemenang Jiwa Sumatera

22. Harkomah, I. (2019). Analisis Pengalaman Keluarga Merawat Pasien Skizofrenia dengan Masalah Halusinasi Pendengaran Pasca Hospitalisasi. Jurnal Endurance, 4(2), 282. https://doi.org/10.22216/jen.v4i2.3844

23. Azizah.Lilik. Ma'rifatul, Zainuri. Imam,\& Akbar. Amar (2016) Buku Ajar Keperawatan jiwa Teori dan Aplikasi Praktik Klinik. Yogyakrata : Indomedia Pustaka.

24. Dermawan, Deden \& Rusdi. (2016). Keperawatan Jiwa; Konsep dan Kerangka Kerja Asuhan Keperawatan Jiwa. Yogyakarta : Pustaka Baru

25. Sutejo (2020). Keperawatan Kesehatan Jiwa Prinsip dan Praktik Asuhan Keperawatan Jiwa. Yogyakarta: Pustaka Baru.

26. Dermawan, Deden \& Rusdi. (2016). Keperawatan Jiwa; Konsep dan Kerangka Kerja Asuhan Keperawatan Jiwa. Yogyakarta : Pustaka Baru

27. Muhiht, Abdul. 2016. Pendidikan keperawatan jiwa: Teori dan Aplikasi. Jakarta: CV Andi Offest

28. Erviana, I., \& Hargiana, G. (2018). Aplikasi Asuhan Keperawatan Generalis Dan Psikoreligius Pada Klien Gangguan Sensori Persepsi: Halusinasi Penglihatan Dan Pendengaran. Jurnal Riset Kesehatan Nasional, 2(2), 114. https://doi.org/10.37294/jrkn.v2i2.106

29. Keliat, B.A \& Akemat. 2016. Model Praktik Keperawatan Profesional jiwa. Jakarta: EGC.

30. Pardede, J. A., Keliat, B. A., \& Wardani, I. Y. (2013). Pengaruh Acceptance And Commitment Therapy Dan Pendidikan Kesehatan Kepatuhan Minum Obat Terhadap Gejala, Kemampuan Berkomitmen Pada Pengobatan Dan Kepatuhan Pasien Skizofrenia. FIK UI, Depok.

31. Sari, H., \& Sirna, W. (2015). Faktor Predisposisi Penderita Skizofrenia Di Poli Klinik Rumah Sakit Jiwa Aceh. Idea Nursing Journal, 6(2), 12-20.

32. Stuart. Gail. W, Keliat. Budi. Anna,\& Pasaribu. Jesika.(2016). Keperawatan kesehal11tan jiwa: Indonesia : Elsever.

33. ECA(2021)https://www.cdc.gov/eis/field-epi-manual/chapters/DescribingEpi-Data.html Diunduh 27 Febuari 2022 
34. Nurlaili, N., Nurdin, A. E., Putri, D. E., Arif, Y., Basmanelly, B., \& Fernandes, F. (2019). Pengaruh tehnik distraksi menghardik dengan spiritual terhadap halusinasi pasien. Jurnal Keperawatan, 11(3), 177-190. 